\title{
Природно-ресурсний потенціал озерних екосистем Турійського району Волинської області
}

У статті описано проблеми впливу антропогенного та природного чинників на стан озер Волинської області. На основі сучасних європейських критеріїв проведено виділення груп та розмежування типів озер Турійського району. Розглянуто можливі способи розв'язання проблеми задля відновлення гідрологічної ролі водойм. Ураховуючи потребу комплексу меліоративних заходів, виконано оцінку природно-ресурсного потенціалу озерних екосистем. Указано розвідані запаси та якісні показники донних відкладів, описано стан прибережної й берегової смуг. Визначено природно-заповідні особливості територій, а також види рослин $\mathrm{i}$ тварин, що занесені до Червоної книги. Проаналізовано законодавче врегулювання ведення господарської діяльності на охоронних територіях. Запропоновано найбільш ефективні способи використання озерних відкладів для різних видів господарської діяльності.

Ключові слова: озеро, басейн, директива, типологія, сапропель.

Постановка наукової проблеми та їі значення. Волинська область володіє значною кількістю озерних екосистем різних за походженням, типом живлення, напрямом використання, впливом на навколишнє середовище. На прикладі озер Турійського району простежено природні умови їх формування та вплив на прилеглі території. Для них характерні різні гідрографічні та геологічні параметри, що зумовлюють формування водного об'єкта, його донних відкладів, водної й берегової рослинності. На стан водних об'єктів впливають наявна інфраструктура навколо водойм, що історично склалася: населені пункти та розораність прибережних і, частково, берегових земель із метою ведення на них сільськогосподарського виробництва з різним ступенем інтенсифікації. Натуралізації озерних систем сприяє їх охорона через різні форми заповідності або відсутність господарської діяльності та віддаленість від населених пунктів й автошляхів.

Ураховуючи антропогенний чинник, озерам властиво швидко та чуттєво реагувати на зміну будь-яких факторів зовнішнього середовища. Незначне порушення вже сформованих екологічних умов водозбору протягом відносно короткого проміжку часу впливає на водний режим озера, кількість поступаючої мінеральної й органічної речовини, умови життєдіяльності організмів, заростання та замулення, що призводить до втрати їхньої гідрологічної ролі й погіршення екологічної ситуації в цілому.

Мета й завдання дослідження - проаналізувати стан озерних екосистем Турійського району для оцінки їхнього природно-ресурсного потенціалу та запропонувати найбільш ефективні шляхи його використання.

Аналіз досліджень цієї проблеми. Підписавши в листопаді 2014 р. Угоду про Асоціацію з СС, Україна взяла напрям на європейські стандарти у сфері водної політики, де основним документом $є$ Водна рамкова директива 2000/60/СС, прийнята 23 жовтня 2000 р. Свропейським парламентом. Ї̈ї мета - можливості співробітництва у сфері покращення екологічного стану поверхневих вод. Опрацювання типології поверхневих вод - основний крок на шляху до встановлення згідно з Директивою оцінки та класифікації екологічного стану вод. Стаття 5 документа вимагає проведення характеристики (оцінки) всіх водних об'єктів і є одним із перших кроків практичного його впровадження щодо стабілізації екологічного стану поверхневих водних об'єктів. Головна мета типології - установлення типоспецифічних референційних умов, які, зі свого боку, виступають відправним пунктом екологічної класифікації [3, с. 33].

Типологія озер при застосуванні системи А спирається на приналежності водних об'єктів до відповідних екорегіонів згідно з виділенням регіонів Іллієсом (1978), представлених у Додатку ХІ Директиви. Подальше розмежування типів озер виконується, спираючись на окреслені геоморфологічні властивості згідно з такими критеріями:

- три класи висоти берегів: $>800,200-800$ i $<200$ м над рівнем моря;

- три класи середньої глибини: дуже мілкі $<3$ м, мілкі 3-15 м і глибокі $>15$ м;

(C) Шевчук М., Сергушко О., 2016 
- чотири класи величини водного дзеркала: малі 50-100 га, середні 100-1000 га, великі 100010000 і дуже великі >10 000 га;

- три види геологічної основи: вапнякова, кременева або органічна [3, с. 118].

У Турійському районі міститься 35 природних озер, що становить $13 \%$ водойм такого типу на Волині. За басейновим розподілом чотири озера розміщені в басейні Західного Бугу та підпадають під водозбірний басейн Вісли й Балтійського моря, а 31 перебуває в басейні річки Прип'ять та відповідає водозбору Дніпра й Чорного моря. Територіально розміщення озер характеризується кучними групами 3 північного заходу на південний схід уздовж уявної лінії через населені пункти Комарів-Дольськ-Соловичі-Радовичі-Озеряни. Таке їх розміщення пов'язане з геологічними процесами часів дніпровського зледеніння, що спричинило їх карстове походження вздовж зазначеної лінії.

У груповому відношенні виділяються озера:

- бузької групи (овлочинської - біля с. Овлочин) - Мале, Велике, Неретва;

- північної - Окунин, Сомин;

- західної (дольської - навколо с. Дольськ) - Дольське, Святе, Бабино, Городжене, Охотники, Мишно, Туричанське, без назви біля с. Растів;

- центральної (турійської - нижче районного центра смт Турійськ) - Кустичі, Селище, Турійське, Клюське, Черепаха, Кошлякоко, Рудно, Батинське, Тагачинське, Велище, Батинське;

- східної (озерянської - вище від с. Озеряни) - Пересіка, Гнильбище, Панське-І, Погоріле, Бережисте, Болотне, Озерянське, Пісочне, Перевірське, Щуче, Зміїнець.

Озера району розміщені в екорегіоні Поліської низовини та щодо висоти над рівнем моря більшість їх розміщена нижче 200 м над рівнем моря й віднесена до класу низинних озер.

Площа їхнього водного дзеркала становить 412,4 га, або 3,1 \% озер області. При цьому сім озер мають площу до 3 га, шість - від трьох до 5 га, шість - від п’яти до 10 га, 13 - від 10 до 25 га й одне понад 100 га (оз. Сомин - 124 га). При середній площі озер 11,8 га вони володіють різними запасами водних ресурсів із загальним об'ємом заакумульованих прісних вод 28,9 млн м³, або 4,1 \% об'єму озер області. Лише шість озер мають об'єм понад 1 млн м³, у тому числі оз. Сомин $(11,1$ млн м³), що за термінологією Водного кодексу України співрозмірне зі штучними водними об'єктами як водосховище. Інші 29 водойм мають менше 1 млн м³ як ставок. 16 озер мають середню глибину до трьох, інші - від трьох до 10 метрів. Максимальні глибини в озерах Сомин (56 м - одне з найглибших на Волині), Дольське (32 м), Бережне та Велике (20 м), Пісочне й Охотники (17 м) [5, с. 24].

Більшість озер басейну розміщені на геологічних утвореннях північного походження на неглибоких закарстованих мергельно-крейдових породах, складених пісками, супісками та глинами, на яких залягають донні відклади у вигляді сапропелю різної товщини, складу і якості.

Сапропелі - мулисті відклади прісноводних водойм, які містять органічні речовини в колоїдному стані, солі кальцію, заліза, фосфору й інших елементів, біологічно активних речовин, що можуть використовуватися в якості ефективного органічного добрива, мінеральної підгодівлі сільськогосподарських тварин і як лікувальні грязі [1, с. 21].

Проведення технічної меліорації озер шляхом екскавації донних відкладів є одним із найбільш дієвих, а нерідко і єдиним способом відновлення замулених і відмираючих водойм. Відновлення гідрологічної ролі озер щодо цього потрібно вважати не лише як охорону й відтворення їхнього ресурсного потенціалу, але і як раціональне використання підводного (донного) ресурсу.

Пошуково-оцінні роботи та детальна розвідка засвідчили, що у 27 озерах (77 \% від їх загальної кількості) загальною площею 267 га промислові балансові запаси сапропелю за категорією $\mathrm{A}+\mathrm{C}_{2}$ становлять 6 млн т, 60 \% вологості. Безпосередньо пошуково-оцінні роботи проведено на 14 озерах, на яких за категорією $\mathrm{C}_{2}$ розвідано 2,2 млн т. Детальна розвідка (за категорією А) проведена на 13 озерах, де розвідано 3,9 млн т [2, с. 167].

Результати пошуково-оцінної та детальної розвідки озер свідчать, що їхній екологічний стан із кожним роком погіршується. У більшості озер евтрофікація набула незворотних процесів, вони втратили гідрологічну роль і поступово заростають, трансформуючись у болота. Дослідженнями

Примітка. Підходи для проведення типології засновані на розмежуванні й класифікації водних об’єктів (озер) згідно з віднесенням до екорегіону та чотирьох дескрипторів. 
встановлено, що нагромадження донних відкладів у водоймищах атмосферно-болотного типу живлення відбувається одночасно як $з$ дна, так і з поверхні площі водозбору.

Площі озер у нульовій границі відкладів сапропелю до 10 га розвідані на 10 озерах, 10-20 га 11 озерах, понад 20 га - двох озерах (озеро Болотне - 39,1 га, Перевірське - 20,2 га). Середня глибина залягання сапропелю - від 2,4 м (Кошляково) до 5,7 м (Мале). Максимальна глибина залягання озерних відкладів у межах від п'яти (Городжене, Селище) до 12 м (Кошляково). Найменші запаси сапропелю $60 \%$ вологості - 24 тис. т (Щуче), найбільші - 630 тис. т (Перевірське, Святе). У співвідношенні запасів сапропелю на 1 га, найпродуктивніші родовища в озерах Городжене (171,3 тис. т/га), Рудно, Тагачинське, Святе (45-60 тис. т/га), менш продуктивні - Дольське, Пісочне, Туричанське (10 тис. т/га).

Найбільш поширеними типами сапропелю є змішаний - 5,5 млн т, діогенний (361 тис. т) та кластогенний (226 тис. т). За класами сапропелю домінують сапропелі карбонатного $(5,4$ млн т), дещо менше - органічного (361 тис. т) та органо-силікатного (226 тис. т) і найменше - залізистого (60 тис. т) класу.

Серед видів сапропелю переважає органо-вапняковий (5,4 млн т - озера Окунин, Кошляково, Рудно, Пересіка, Гняльбище, Озерянське, Велике, Мале, Туричанське, Городжене, Святе, Кустичі, Селище, Клюське, Тагачинське, Перевірське, Охотники), трапляються змішано-водоростевий (335 тис. т Бережне, Болотне, Велище, Мишно, Погоріле, Щуче), органо-піщаний (226 тис. т - Дольське, Пісочне), органо-залізистий (60 тис. т - Турійське) та торф'янистий (26 тис. т - Неретва) види.

За гідрологічним режимом більшість озер є безстічними із замкнутою площею водозбірної території, озера Кошляково й Святе - проточні, а озера Неретва та Пісочне - стічні. У багатьох озерах берегова смуга по всьому периметру заросла водно-болотними видами гігрофітів: рогозом, аїром, очеретом, ситником, осокою в глибину 10-40 м від берега (Болотне, Клюське, Неретва, Окунин, Турійське).

Береги за рельєфом - від низьких (Туричанське, Святе) і пологих (більшість озер) до припіднятих (Велике, Охотники) та висотою 2-3 метри (Мале, Окунин, Неретва). За складом грунтів трапляються береги заторфовані (Гняльбище, Кошляково, Мале, Рудно, Святе, Туричанське, Щуче), суглинкові (Городжене) і піщані (Бережне, Охотники, Пересіка, Турійське). Традиційно береги зарослі чагарниками, вербою, вільхою, березою, а по берегах частини озер розміщені змішані лісові насадження [2, с. 167-183].

Довкола окремих озер сформувалися населені пункти, мешканці яких ведуть господарську діяльність безпосередньо на берегах (Велике, Кустичі, Охотники, Селище) або використовують їх під сінокоси (Тагачинське).

Для запобігання впливу й ведення негативної антропогенної діяльності на озерні екосистеми, деякі $з$ них, за рішенням обласної влади 1992-1994 рр., охороняються як природно-заповідні території:

- гідрологічний заказник «Озеро Велике» площею 16 га охороняє одне з найглибших (понад 20 м) озер карстового походження в заплаві річки Турія. Його характерною особливістю є прозора та чиста вода, яка за хімічним складом відповідає господарсько-питним критеріям, злаково-осокові й очеретяні асоціації рослин та типова для регіону іхтіофауна. Із птахів водяться лебеді-шипуни, види водоплавних водних птахів - крижень, чирки, мартини, кулики та горобцеподібні;

- гідрологічний заказник «Озеро Олеандра» площею 16 га охороняє озеро карстового походження глибиною до 11 м із чистою прозорою водою, де трапляється вугор річковий;

- гідрологічний заказник «Озеро Святе» площею 11,3 га охороняє мальовниче озеро карстового походження завглибшки до 4,5 м, яке оточене лісом, частково замулене та $є$ місцем гніздування багатьох видів птахів, а також проживання видри річкової й інших видів, занесених до Червоної книги України.

У Турійському районі наявні заповідні території, до яких входять цілі групи озер як складові частини природно-охоронного комплексу:

- загальнозоологічний заказник «Соловичівський» площею 1326 га, що охороняє комплекс лісових масивів сосново-березових насаджень і включає сім озер площею 52 га. У заказнику трапляються понад 20 видів ссавців та 50 видів птахів, у тому числі лелеки чорного й журавля сірого, занесених до Червоної книги;

- загальнозоологічний заказник «Озерянський» площею 2736 га, у тому числі 12 озер площею 67 га, що об'єднує сосново-дубові й березово-осикові ліси. Тут проживають козуля європейська, лисиця, 
заєць-русак, білка, куниця лісова, низка видів птахів, а також видра річкова та журавель сірий, які занесені до Червоної книги [4, с. 42-43].

Тимчасову господарську діяльність нині (за договорами оренди) проводять на 21 озері (площа 161,7 га та об'єм - 10 млн м ${ }^{3}$ ) в основному для рибогосподарських цілей.

Із початком дії Закону України «Про аквакультуру» та 3 унесенням змін до Водного кодексу України введені повні обмеження на оренду водних об'єктів у межах природно-заповідного фонду для рибогосподарських потреб. Тобто по закінченню строків оренди на таких об'єктах продовження строку дії договору або укладення нового можливе для всіх цілей (культурно-оздоровчих, лікувальних, рекреаційних, спортивних і туристичних цілей, проведення науково-дослідних робіт), крім рибогосподарських [5, с. 65].

Якісні характеристики донних відкладів указують на те, що їх можна використовувати як добриво для сільського господарства, особливо для кислих грунтів. Органо-вапняковий вид донних відкладів, якого тут найбільше, рекомендується до використання в якості мінерально-вітамінних добавок до корму та у ветеринарних цілях у галузі тваринництва. Сапропелі органічного класу (озера Бережне, Велище, Мишно, Щуче) як добавки до цементно-піщаних сумішей можуть застосовуватися для виробництва будівельних матеріалів (дренажних труб, будівельного каменю, бурових розчинів). Аналогічні їм види застосовують у грязевій терапії й для виробництва препаратів серцево-судинної дії, загоювальних ліків, антибіотиків [2, с. 28-30].

Висновки й перспективи подальших досліджень. Ураховуючи оцінку сучасного екологічного стану озер Турійського району, причини їх прискореної евтрофікації, помічаємо необхідність ужиття заходів із відновлення їхнього гідрологічного режиму в межах, які б забезпечили різноцільове функціонування водойм. Ступінь й інтенсивність змін характеристик екосистеми озер значною мірою залежить від обсягів і швидкості екскавації донних відкладів, кінцевим результатом яких $є$ поглиблення дна озера, зміна глибини води, ріст об'єму водної маси та зменшення швидкості водообміну видового складу й рівня розвитку гідробіонтів, що призводить до стабілізації газового та температурних режимів.

Обгрунтовуючи добування й використання сапропелів, доцільно передбачати екологічно безпечні технології їх екскавації та переробки добутої сировини, а також зарезервувати найбільш цінні родовища (озера Велике, Окунин, Перевірське, Святе, Щуче) як природоохоронні об'єкти.

\section{Джерела та література}

1. Шевчук М. Й. Сапропелі України: запаси, якість та перспективи використання / М. Й. Шевчук. Луцьк : Надстир'я, 1996. - 384 с.

2. Леймунский А. С. Справочник ресурсов сапропеля Украины : в 3 кн. - Кн. І. : Волынская область / А. С. Леймунский. - Киев : Гос. ком. Украины по геологии и использовании надр, 1994. - 193 с.

3. Алієв. К. Водна Рамкова Директива ЄС 2000/60/ЄС. Основні терміни та їх визначення / К. Алієв, Ю. Відєніна, Н. Закорчевна - К., 2006. - 240 с.

4. Химин М. Природно-заповідний фонд Волинської області / М. Химин, В. Тутейко, О. Грицай ін. Луцьк : Ініціал, 1999. - 48 с. : ілюстр., карти.

5. Річний звіт про діяльність Волинського облводресурсів за 2014 р. із комплексного використання водних ресурсів на території області й проведення на малих річках і водоймах природоохоронних заходів. - Луцьк : Волин. обл. упр. водних ресурсів, 2015. - 90 с.

Шевчук Михаил, Сергушко Александр. Природно-ресурсный потенциал озерных экосистем Турийского района Волынской области. В статье описаны проблемы влияния антропогенного и природного факторов на состояние озер Волынской области. На основе современных европейских критериев проведено выделение групп и определение типов озер Турийского района. Рассмотрены возможные пути решения проблемы с целью восстановления гидрологической роли водоемов. Учитывая необходимость комплекса мелиоративных мероприятий, выполнена оценка природно-ресурсного потенциала озерных экосистем. Указаны разведанные запасы и качественные показатели донных отложений, описано состояние прибрежной и береговой полосы. Отмечены природно-заповедные особенности территорий, а также виды растений и животных, занесенных в Красную книгу. Проанализировано законодательное урегулирование ведения хозяйственной деятельности на охраняемых территориях. Предложены наиболее эффективные пути использования озерных отложений для различных видов хозяйственной деятельности.

Ключевые слова: озеро, бассейн, директива, типология, сапропель.

Shevchuk Myhailo, Serhushko Oleksandr. Natural and Resource Potential of the Lacustrine Ecological Systems of Turiysk District of Volyn Region. This article describes the influence of anthropogenic and natural 
factors on the lakes of Volyn region. The differentiation of groups and types of lakes of Turiysk district, based on the current European criteria, is conducted. The possible solutions of the problem are considered with the aim of preceding the hydrological role of reservoirs. Taking into account the necessity of land reclamation complex measures the estimation of natural resources of lake ecosystems is executed. The explored supplies and quality of bottom sediments are indicated and the state of coastal and riverside is described. The natural protected features of areas, kinds of plants and animals listed in the Red Book are indicated. The legislative regulation of business activity on the protected areas is analyzed and the most effective ways of lake sediments application for various types of economic activity are offered.

Key words: lake, basin, directive, typology, sapropel.

\section{Екологічний аспект просторової неоднорідності едафотопів техногенного походження}

Досліджено динаміку просторової неоднорідності педозему ділянки рекультивації Нікопольського марганцеворудного басейну в м Орджонікідзе за показниками твердості. Проведено екоморфічний аналіз рослинності ділянки. Методом неметричного багатовимірного шкалювання здійснено ординацію даних твердості грунту. Застосовано тривимірний варіант багатовимірного шкалювання. Виділено характерні для вивченого грунту типи розподілу твердості за профілем. Взаємозв'язок варіювання твердості грунту й факторів навколишнього середовища встановлено при використанні фітоіндікаційних шкал. За допомогою техніки просторового аналізу даних (PCNM) виділено просторові структури на різних масштабних рівнях і визначено процеси, що лежать у їх основі.

Ключові слова: твердість грунту, екоморфічний аналіз, педозем, багатовимірне шкалювання.

Постановка наукової проблеми та її значення. Існування закономірної неоднорідності грунтів на невеликих відстанях $є$ доказом множинності будови і властивостей грунтів та наслідком різноспрямованої дії факторів грунтоутворення й особливо складних і суперечливих взаємозв’язків грунтового тіла з рослинністю та кліматом $[13,17,19]$. Видима просторова структура проявляється на різних масштабних рівнях і $€$ результатом причин абіотичного, біологічного й історичного характеру, що доповнюють одна іншу [28, 29]. Просторова неоднорідність грунтів порушених промисловістю земель є актуальним предметом наукових досліджень у зв'язку зі зростаючою інтенсивністю антропогенного пресу та питаннями господарського призначення порушених територій [4].

Виходячи із закону єдності «організм-середовище», за В. І. Вернадським, життя розвивається в сукупній єдності середовища й організмів, що іiі населяють. Відносини організму та середовища $є$ системними, у них діє принцип екологічної відповідності: форма існування організму завжди відповідає умовам життя $[5,19]$. Установлено, що судинні рослини проявляють свій біоекологічний потенціал в екстремальних умовах техногенного середовища, пристосовуючись до нього відповідно до своїх біологічних й екологічних особливостей. У техногенних екотопах зростання, розвиток і зовнішній вигляд рослин залежать від того, наскільки відповідають екологічні умови місцеперебування вимогам тих чи інших видів. Взаємозв'язок між фізико-хімічними характеристиками субстратів і процесами сінгенезу рослинності на едафотопах техногенного походження дає можливість використовувати фітокомпоненту як інтегральний показник стану техногенних екотопів та біогеоценозів, що формуються [5]. Функціональна цілісність біогеоценозу передбачає, що грунт повинен проявляти морфологічно й функціонально свою відповідність іншим його компонентам. Показником грунтових властивостей, що має інтегральність і високу інформативність, є твердість грунту [15]. Варіювання твердості грунту в просторі достовірно корелює 3 такими показниками, як проективне покриття, фітомаса, агрегатний склад верхнього шару грунту і його електропровідність [3, 10, 11]. Твердість грунту є лімітуючим фактором для рослинного покриву. Глибина виникнення граничної твердості бере участь у формуванні ділянки екологічного простору з найбільшими продукційними характеристиками, а наближення порогової твердості до поверхні грунту пов’язане зі зміною видового багатства досліджуваного рослинного угрупування.

(C) Задорожна Г., 2016 